\title{
Management of inhalation injury and respiratory complications in Burns Intensive Care Unit
}

\author{
Yanık yoğun bakım ünitesinde inhalasyon yaralanması ve \\ solunum komplikasyonlarının yönetimi
}

Afife Ayla KABALAK, Ahmet Çınar YASTI

\section{BACKGROUND}

Inhalation injury has high mortality and carries a significant risk of permanent pulmonary dysfunction. Inhalation injury and its consequences impose difficulties for the respiratory therapists, nurses and doctors who play a central role in its clinical management. In this study, we aimed to report our clinical experience and the role of non-invasive mechanic ventilatory (NIMV) support in a series of inhalation-injured patients.

\section{METHODS}

Patients hospitalized at Ankara Numune Training and Research Hospital's Burns Intensive Care Unit between March 2009 and March 2011 was reviewed, and patients with required respiratory support due to inhalation injury were included in the study.

\section{RESULTS}

Among the patients, 37 had inhalation injury, and their mortality was $13.5 \%$. Of the 37 patients, 16 had mandatory intubation (6 in the first 6 hours and 10 in the clinical course); however, others (67.8\%) had only NIMV support.

\section{CONCLUSION}

Application of NIMV support with proper modes decreases the need for invasive procedures in inhalation-injured patients. Based on our results, we propose the application of NIMV support in inhalation-injured burn patients.

Key Words: Inhalation injury; medical treatment; respiratory management; ventilatory support.

\begin{abstract}
AMAÇ
İnhalasyon yaralanması yüksek mortalite oranlarına sahiptir ve belirgin kalıcı pulmoner fonksiyon bozukluğu riski taşımaktadır. İnhalasyon yaralanması ve sonuçları, klinik yönetiminde ana rol oynayan solunum terapistlerine, hemşirelere ve doktorlara ciddi zorluklar oluşturur. Çalışmamızda inhalasyon yaralanmalı hasta serimizdeki klinik tecrübelerimizi ve noninvazif mekanik ventilatör (NIMV) desteğinin rolünü bildirmeyi amaçladık.
\end{abstract}

\section{GEREÇ VE YÖNTEM}

Ankara Numune Eğitim ve Araştırma Hastanesi Yanık Yoğun Bakım Ünitesi'nde Mart 2009 - Mart 2011 yılları arasinda yatarak tedavi alan hastalardan inhalasyon hasar1 nedeniyle solunum desteğine ihtiyaç duyanlar çalışmaya alindi.

\section{BULGULAR}

$\mathrm{Bu}$ hastaların 37'sinde inhalasyon yaralanması vardı, mortalite oranı \%13,5 olarak bulundu, hastaların 16'sında zorunlu entübasyon uygulanırken (altı hastada ilk 6 saatte ve 10 hastada klinik seyir sürecinde) diğer hastalara sadece $(\% 67,8)$ NIMV desteği uyguland.

\section{SONUÇ}

NIMV desteğinin uygun modlarda uygulanması, inhalasyon yaralanmalı olgularda invaziv yöntemlerin gerekliliğini azaltmaktadır. NIMV desteğinin inhalasyon yaralanmalı yanık hastalarında uygulanmasını önermekteyiz.

Anahtar Sözcükler: İnhalasyon yaralanması; medikal tedavi; solunum yönetimi; ventilatör desteği. 
Inhalation injury is very common in patients who sustain burns and it has high morbidity and mortality rates. Even isolated inhalation injury can carry a significant risk of mortality or permanent pulmonary dysfunction. When combined with cutaneous burns, inhalation injury increases fluid requirements for resuscitation, ${ }^{[1]}$ the incidence of pulmonary complications, ${ }^{[2]}$ and the mortality rate. ${ }^{[2-4]}$

Inhalation injury is produced by either thermal or chemical irritation due to inspiration of smoke, burning embers, steam, or other irritant or cytotoxic materials in the form of fumes, mists, particulates, or gases. $[3,5,6]$ The damage can be the result of direct cytotoxic effects of the aspirated materials or a consequence of the inflammatory response. In addition to damage to the airways and pulmonary parenchyma, inhalation of toxic substances such as carbon monoxide or cyanide can produce detrimental systemic effects. ${ }^{[7,8]}$

In recent decades, there has been a dramatic decline in the mortality of large burns. In contrast, despite considerable advances in our knowledge of the pathophysiology of inhalation injury, there are few specific therapeutic options, and patient care is mainly supportive. Although several studies have suggested a decrease in the mortality associated with inhalation injury, these changes would result from overall improvements in care and not so much from interventions aimed specifically at inhalation injury. It is imperative that a well-organized, protocol-driven approach to respiratory management of burn care be utilized so that improvements can be made, and the morbidity and mortality associated with inhalation injury can be reduced.

The goal of this study was to assess whether early application of non-invasive mechanical ventilation (NIMV), medical treatment, respiratory physiotherapy, and nutritional support is effective in a series of inhalation-injured patients.

\section{MATERIALS AND METHODS}

The medical records of all patients with inhalation injury hospitalized at the Ankara Numune Training and Research Hospital, Burn Treatment Center between 1 March 12009 and 1 March 2011 were reviewed. A total of 697 patients were hospitalized, and of them, 234 were inpatients in the intensive care unit (ICU) of the Burns Center. Of the ICU patients, 97 required respiratory support due to acute respiratory failure. While inhalation injury was the diagnosis in 37 patients, others had secondary pulmonary damage, acute respiratory distress syndrome (ARDS), sepsis, and multi-organ failure on their first admission to hospital.

Inhalation injury was documented based on history, physical findings, arterial blood gas monitoring, serial chest radiography, and serial fiberoptic bronchoscopy in all cases. Indication for the endotracheal intubation and ventilation and $\mathrm{PaO}_{2} / \mathrm{FiO}_{2}$ values of the patient just prior to institution of invasive positive pressure ventilation (IPPV) and/or non-invasive positive pressure ventilation (NIPPV) were noted. The cause of respiratory failure, ventilator modes, pressures, and whether intubation/re-intubation was done were also recorded. The diagnosis of pneumonia was made regarding presence of hyperthermia $\left(>38.2^{\circ} \mathrm{C}\right)$, leukocytosis (white blood cells $[\mathrm{WBC}]>15 \times 10^{9} / \mathrm{L}$ ), positive sputum cultures, and radiographic identification of infiltrates.

IPPV and NIPPV were delivered using Nellcor Prutan Bennett 840 ventilators. The BiLevel Positive Airway Pressure+Pressure Control mode with timed cycling (BiLevel+PC) was used for IPPV. Bilevel+PC ventilation provides two ventilatory pressures: The Inspiratory Positive Airway Pressure (PEEPhigh) and the Expiratory Positive Airway Pressure (PEEPlow).

Pressure support ventilation has been shown to improve tidal volume, gas exchange, respiratory rate, and diaphragmatic activity in proportion to the amount of pressure supplied. The Continuous Positive Airway Pressure (CPAP) ventilation mode was used for NIPPV at spontaneous breathing. CPAP prevents or helps re-open collapsed alveoli and atelectasis of lung zones and is often used to facilitate weaning.

NIPPV was applied to patients who were hemodynamically stable, conscious and alert. IPPV is the choice of procedure at endotracheal intubation to protect the airway (large facial burn, obstructive airway edema) or to remove excessive tracheobronchial secretions or in case of large facial burn. Evidence of acute respiratory failure had to be exhibited by the patient, and this was defined as acute hypoxemia where the $\mathrm{PaO}_{2} / \mathrm{FiO}_{2}$ ratio was $\leq 40 \mathrm{kPa}$. This value is part of the definition for an acute lung injury (ALI).

The pressures for NIPPV (CPAP) set on the ventilator were kept low initially (Ppeak $=8-10 \mathrm{cmH}_{2} \mathrm{O}$, PEEP $=8 \mathrm{cmH}_{2} \mathrm{O}$ ). NIPPV was used every 2 hours (h) for 15-minute (min) periods. Most patients were allowed to remove their masks for a few minutes for talking, mobilization or in some cases to drink small amounts of water.

The pressures for IPPV (BiLevel + PC) set on the ventilator were low initially (PEEP high: PEEP low + Psupport $=10-12 \mathrm{cmH}_{2} \mathrm{O}$, PEEP low $=4-6 \mathrm{cmH}_{2} \mathrm{O}$ ). The pressures were titrated upwards according to the patient's tolerance and arterial blood gas results (the maximum pressures used were PEEP high: PEEPlow + Psupport $=23 \mathrm{cmH}_{2} \mathrm{O}$, PEEP low $=8 \mathrm{cmH}_{2} \mathrm{O}$ ).

All patients received chest physiotherapy while on NIPPV and IPPV to assist expectoration of secretions 
and reversal of atelectasis, twice daily in routine practice and additionally where required. A saline nebulizer was in the circuit and, if prescribed, bronchodilator, heparin, N-acetylcysteine (NAC), and corticosteroid was given. Bed positions were changed frequently in all patients. Fluid-electrolyte replacement, intravenous vitamin $\mathrm{C}$ and nutritional support with a high content of protein were performed in all patients.

Age, sex, burned total body surface area (TBSA), and whether burn surgery was performed were recorded for all patients.

\section{RESULTS}

All patients received routine burn management, mechanical ventilation and supportive treatment according to the Unit's protocols. A total of 37 patients were included in the study. Baseline characteristics and the clinical course of the patients are shown in Table 1. There were four females, the mean age was 41 years (21-76 years), and burned TBSA was a mean $28.2 \%$ (range: $18-54 \%$ ). The etiologies of the injuries were flame and smoke, and the diagnosis was made by fiberoptic bronchoscope examination in 31 patients; the remaining six patients sustained large burns to the face. A total of 29 patients underwent burns surgery and 24 had early excision of deep partial-thickness and full-thickness burns. Wound closure was achieved either temporarily by wound dressing and/or using skin substitutes or permanently with split thickness auto grafts. The pre-morbid conditions of the patients are summarized in Table 2. Some of the victims had additional traumas at the time of the inhalation injury (Table 3).

Six patients required urgent endotracheal intubation and invasive mechanical ventilation (IMV) support (because of extensive facial burn) for a period of 1-29 days. Ventilator support was continued with NIPPV after extubation. NIPPV was well tolerated by the patients in general. Regarding the patient records, low pressures were initiated until the patient cooperated to breathe on the ventilator. NIPPV was used for prophylaxis in 21 patients $\left(\mathrm{PaO}_{2} / \mathrm{FiO}_{2}>40 \mathrm{kPa}\right)$ to prevent further respiratory deterioration and endotracheal intubation or re-intubation. Therapeutic NIPPV was applied to 10 patients with $\mathrm{PaO}_{2} / \mathrm{FiO}_{2}$ ratio $<40 \mathrm{kPa}$.

Pneumonia suspicion was documented in 25 patients. Of these 25, eight patients received IPPV as they were accepted to have high risk of developing respiratory complications after sustaining sepsis, systemic inflammatory response syndrome (SIRS), ARDS, pleurisy, and hemopneumothorax (3 patients had 1 and 2 had 2 re-intubations). Postoperatively, two patients had continuous ventilator support for 2-3 days and shift to NIPPV in the following days. Four patients with severe inhalation injury requiring long-
Table 1. Demographics and clinical course of the patients

\begin{tabular}{lc}
\hline Variable & Patients \\
\hline Number of patients & 37 \\
Age (mean, in year) & 41.38 (range: $21-76$ ) \\
Female/Male & $4 / 27$ \\
TBSA (mean \%) & 28.2 (range: $18-54$ ) \\
Facial burns (extensive/mild) & $6 / 21$ \\
Burns surgery & 29 \\
Diagnostic fiberoptic bronchoscopy & 31 \\
Intubated and ventilated & \\
(emergency/late period) & $6 / 10$ \\
Tracheostomy & 4 \\
Ventilation days (mean) & 8.1 (range 1-29) \\
\hline
\end{tabular}

TBSA: Total body surface area.

Table 2. Pre-morbid conditions of the patients

\begin{tabular}{lc}
\hline Medical condition/surgery & Patients \\
\hline Chronic obstructive pulmonary disease & 8 \\
Hypertension & 8 \\
Diabetes mellitus & 7 \\
Left-ventricular failure & 5 \\
Right-ventricular failure & 1 \\
Chronic renal failure & 4 \\
Epilepsy & 3 \\
Dementia & 2 \\
Schizophrenia & 1 \\
Stroke & 1 \\
Carcinoma of the prostate & 1 \\
\hline
\end{tabular}

Table 3. Additional injuries sustained by the patients

\begin{tabular}{lc}
\hline Nature of injury & Patients \\
\hline Head injury & 1 \\
Subarachnoid hemorrhage & 1 \\
Hemopneumothorax & 1 \\
Extremity fractures & 2 \\
Tendon ruptures & 2 \\
\hline
\end{tabular}

term ventilator support and frequent tracheal toilet underwent tracheostomy procedure.

The most common cause of respiratory deterioration is shown in Table 4. In some patients, while pneumonia was the primary cause, another respiratory pathology was deemed to contribute to the acute respiratory failure.

Our Burn Center's routine pulmonary treatment protocol is summarized in Table 5.

Emergent intubation and mechanical ventilation were indicated in six patients (16.2\%). Intubation/reintubation was successfully avoided in 21 of the 37 
Table 4. The cause of acute respiratory failure

\begin{tabular}{lc}
\hline Cause & Patients \\
\hline Upper airway edema & 6 \\
Pneumonia & 25 \\
Bronchospasm & 12 \\
SIRS & 6 \\
ARDS & 4 \\
Pleurisy & 9 \\
\hline
\end{tabular}

SIRS: Systemic inflammatory response syndrome; ARDS: Acute respiratory distress syndrome.

Table 5. Medical and supportive treatment protocols for lung healing

\begin{tabular}{lc}
\hline Treatment modalities & Ventilatory modes \\
\hline Chest physiotherapy & NIPPV / IPPV \\
Position change & NIPPV / IPPV \\
Prone position & NIPPV \\
Saline nebulizer, inhaler & NIPPV / IPPV \\
Heparin nebulizer, inhaler & NIPPV / IPPV \\
NAC nebulizer, inhaler & NIPPV / IPPV \\
Corticosteroid nebulizer, inhaler & NIPPV / IPPV \\
Bronchodilator & NIPPV / IPPV \\
Tracheal aspiration & IPPV \\
Tracheal lavage & IPPV \\
Bronchoalveolar lavage by & \\
fiberoptic bronchoscopy & IPPV \\
Recruitment maneuver & IPPV \\
\hline
\end{tabular}

(56.7\%) patients (Table 6). Intubation/re-intubation and IMV were indicated due to acute respiratory failure and hemodynamic instability in $10(32.2 \%)$ of the 31 patients.

The patients' outcomes after treatment for the 37 patients are demonstrated in Table 7. Five patients died due to multi-organ failure as a result of burns with inhalation injury.

\section{DISCUSSION}

Inhalation injury is a nonspecific term describing the harmful effects of inspiration of any of a large number of materials that can damage the airways or pulmonary parenchyma. The formation of reactive oxygen and nitrogen species, as well as the procoagulant and antifibrinolytic imbalance of alveolar homeostasis, all play a central role in the pathogenesis of smoke inhalation injury. ${ }^{[9]}$ The pathology of the upper and lower respiratory tract lesions is due to the formation of edema, mucosal casts, and tenacious secretions. ${ }^{[3]}$ Focal areas of congestion and edema are seen, alternating with the areas of collapse and pneumonia, which are the results of compensatory emphysema. ${ }^{[7]}$ As a result, pulmonary compliance decreases, which can be more than $50 \%$. In severe injuries, physiologic shunt lead-
Table 6. Respiratory results of patients treated with NIPPV and IPPV

\begin{tabular}{lcc}
\hline Ventilatory support & Patients & Percentage \\
\hline Emergency intubation & $6 / 37$ & 16.2 \\
Intubation/reintubation & $16 / 37$ & 43.7 \\
Intubation/reintubation (after NIPPV) & $10 / 31$ & 32.2 \\
\hline
\end{tabular}

NIPPV: Non-invasive positive pressure ventilation; IPPV: Invasive positive pressure ventilation.

Table 7. Patient outcomes

\begin{tabular}{lcc}
\hline Outcome & Patients & Percentage \\
\hline Self-ventilation & 23 & 62 \\
COPD requiring treatment & 9 & 35 \\
Mortality & 5 & 13.5 \\
\hline COPD: Chronic obstructive pulmonary disease. & &
\end{tabular}

ing to profound hypoxemia and acute microvascular injury with increased transvascular fluid flux produces a clinical picture of ARDS. Furthermore, in burn patients, multiple mechanisms, besides inhalation injury, may contribute to ALI (e.g., sepsis, ventilator-induced injury, or SIRS to the burns). ${ }^{[10]}$

In the clinical setting, diagnosis of inhalation injury is usually a subjective decision based on a combination of history and physical examinations, and is confirmed by diagnostic studies (e.g., fiberoptic bronchoscopy, xenon scanning, carboxyhemoglobin level, estimation of extravascular lung water by thermal and dye dilution). Defining the diagnostic criteria for inhalation injuries is complicated due to the extreme heterogeneity of clinical presentation as evaluated by the criteria above. Another difficulty is encountered when one attempts to distinguish between exposure to inhaled irritants and inhalation injury. Our clinical experience is that progressive respiratory failure does not always appear proportional to the exposure to smoke. These differences are likely due to the composition of the inhaled materials and/or differences in host response such as levels of antioxidants or inflammatory response. ${ }^{[11]}$ Bronchoscopy of the airway is still the gold standard to detect a pathognomonic mucosal hyperemia. Chest radiographs may show signs of diffuse atelectasis, pulmonary edema or bronchopneumonia. However, during the initial period, the degree of injury is usually underestimated based on the chest X-ray, as the injury is mainly confined to the airways. ${ }^{[12]}$

There is no consensus regarding standards for treatment of inhalation injury; however, treatment options are determined by the availability of resources and local tradition. ${ }^{[13]}$ Patients with combined smoke inhalation injury and cutaneous burns are well known to 
be more hemodynamically unstable than patients with cutaneous burn injury alone. Acute airway obstruction is a major hazard because of the possibility of rapid progression (the first $12 \mathrm{~h}$ after insult). For patients with large surface burns that require rapid fluid administration, these changes may be accentuated. ${ }^{[14]}$

Endotracheal intubation and PPV are commonly used to prevent or treat hypoxia and to secure a patent airway in the patient. ${ }^{[15]}$ Ventilation protocols differ not only between different burn centers but also between individual physicians. Apart from conventional pressure-controlled low tidal volume ventilation, multiple strategies for mechanical ventilation are currently in use for the treatment of smoke inhalation injury, isolated as well as in combination with burns. Upper airway injuries and their sequelae continue to be major management problems in the care of patients with burn and inhalation injuries. However, the presence of the endotracheal tube introduces problems by bypassing the protective mechanisms of the upper airway, increasing the incidence of nosocomial pneumonia and damage to the airway resulting in tracheal stenosis. ${ }^{[16]}$ Factors contributing to the risk of developing acute respiratory complications in burn patients include ventilatory restriction caused by the pain and tightness of abdominal and chest burns, autografts and donor sites. The presence of injuries to the thoracic cage or within lung tissue compounded the restriction and introduced problems with sputum retention and airway plugging. One other factor that we found to increase the risk of respiratory complications is frequent general anesthesia. This is associated with reduced lung volumes and is necessary with a major burn-injured patient to enable wound care and surgical procedures. To avoid anesthesia-induced pulmonary complications, indications for surgery must be determined while taking its likelihood into consideration. Also, patients who are immobilized in bed for prolonged periods of time have a reduced functional residual capacity and therefore are more likely to develop airway atelectasis. Prophylaxis with NIPPV can be applied to prevent further respiratory complications. ${ }^{[17]}$

In our burn-injured patients with acute respiratory failure, NIPPV appears to be effective in supporting respiratory function such that endotracheal intubation could be avoided in most cases. Moreover, we also found that NIPPV facilitated earlier weaning of mechanical ventilation and extubation. Once the patient is established on the ventilatory support, they are extubated and commenced on mask ventilation, which consequently provides earlier initiation of an active rehabilitation program. However, the patient must fulfill the selection criteria for NIPPV to ensure a smooth transition from IMV to NIPPV and ultimately to selfventilation. During the last two decades, IMV has been studied extensively. Low tidal volume ventilation with associated permissive hypercapnia has been shown to effectively reduce ventilator-induced lung injury, and currently represents the standard of care. ${ }^{[18]}$

Appropriate fluid resuscitation in patients with smoke inhalation injury is still subject to controversial debates. ${ }^{[19]}$ This, of course, does not inevitably indicate that isolated smoke inhalation injury is associated with increased fluid requirements. By contrast, overresuscitation may increase pulmonary microvascular pressures and might thereby lead to increased edema formation under the high permeability conditions in early lung injury. In our opinion and based on the literature, fluid resuscitation should be guided by urinary output and hemodynamic parameters of the individual patient. In this regard, dynamic parameters, such as change in pulse pressure, rather than static parameters, such as central venous or pulmonary artery occlusion pressures, might be helpful. ${ }^{[20]}$

Contrary to popular belief that the lung is the primary injured organ following smoke inhalation injury and that mechanical ventilation is frequently necessary, administration of therapeutic compounds via nebulization directly to the affected organ seems to be more reasonable. Based on the complex pathogenesis of smoke inhalation injury, drugs with different mechanisms of action, such as bronchodilators, anticoagulants, antioxidants, and corticosteroids, have been studied. In each case, however, the key to any successful aerosol therapy is to deliver into the lung and to the distal airways. Owing to increased procoagulatory activity following smoke inhalation injury, ${ }^{[21]}$ the aerolized administration of anticoagulants seems to be more than promising. In a bovine model, Brown et al. ${ }^{[22]}$ first described a reduction in mortality after smoke inhalation-induced ARDS by using aerolized heparin. In children with combined burn and smoke inhalation injury, nebulization of heparin and NAC significantly decreased re-intubation rates, the incidence of atelectasis and mortality. ${ }^{[23]}$ We observed that nebulization of heparin and NAC was beneficial in patients. Aerolized epinephrine or corticosteroids have been proposed as therapeutic approaches in progressive upper airway edema; ${ }^{[15]}$ however, conclusive evidence for these treatment strategies is still lacking. We prefer to initiate with aerolized corticosteroids for the first four days and than shift to intravenous route. As mentioned earlier, following combined burn and smoke inhalation injury, the oxidative-antioxidative balance is disturbed by an increase in reactive oxygen species and a parallel decrease in antioxidants. Accordingly, the antioxidant vitamin $\mathrm{C}, \mathrm{E}$ or $\alpha$-tocopherol is markedly reduced in patients with major burns and combined smoke inhalation injury. ${ }^{[24,25]}$ We prefer to give intravenous vitamin $\mathrm{C}$ as an antioxidant. In our 
experience, administration of anticoagulants, antioxidants and bronchodilators currently represent the most promising effective treatment strategies.

Against the background of the current literature, there has been a remarkable increase in our knowledge regarding the pathogenesis of smoke inhalation injury during the last two decades. There are several promising therapeutic approaches, such as bronchodilators, antioxidants or anticoagulants, and nebulization of the use of different ventilation modes. In inhalation-injured patients with acute respiratory failure, NIPPV appears to be effective in supporting respiratory function such that endotracheal intubation can be avoided in most cases. There is a need for further researches and multi-center trials to acquire a larger sample size, and prospective studies would enable standardization of monitoring. To achieve this goal, the cooperation and communication between burn centers should be intensified.

\section{REFERENCES}

1. Dai NT, Chen TM, Cheng TY, Chen SL, Chen SG, Chou $\mathrm{GH}$, et al. The comparison of early fluid therapy in extensive flame burns between inhalation and noninhalation injuries. Burns 1998;24:671-5.

2. Shirani KZ, Pruitt BA Jr, Mason AD Jr. The influence of inhalation injury and pneumonia on burn mortality. Ann Surg 1987;205:82-7.

3. Head JM. Inhalation injury in burns. Am J Surg 1980;139:50812.

4. Tredget EE, Shankowsky HA, Taerum TV, Moysa GL, Alton JD. The role of inhalation injury in burn trauma. A Canadian experience. Ann Surg 1990;212:720-7.

5. Haponik E. Smoke inhalation injury: some priorities for respiratory care professionals. Resp Care 1992;37:69-612.

6. Einhorn IN. Physiological and toxicological aspects of smoke produced during the combustion of polymeric materials. Environ Health Perspect 1975;11:163-89.

7. Walker HL, McLeod CG Jr, McManus WF. Experimental inhalation injury in the goat. J Trauma 1981;21:962-4.

8. Nieman GF, Clark WR Jr, Wax SD, Webb SR. The effect of smoke inhalation on pulmonary surfactant. Ann Surg 1980;191:171-81.

9. Rehberg S, Maybauer MO, Enkhbaatar P, Maybauer DM, Yamamoto Y, Traber DL. Pathophysiology, management and treatment of smoke inhalation injury. Expert Rev Respir Med 2009;3:283-297.

10. Enkhbaatar P, Traber DL. Pathophysiology of acute lung in- jury in combined burn and smoke inhalation injury. Clin Sci (Lond) 2004;107:137-43.

11. Sherwood ER, Toliver-Kinsky T. Mechanisms of the inflammatory response. Best Pract Res Clin Anaesthesiol 2004; 18:385-405.

12. Lee MJ, O'Connell DJ. The plain chest radiograph after acute smoke inhalation. Clin Radiol 1988;39:33-7.

13. Woodson LC. Diagnosis and grading of inhalation injury. J Burn Care Res 2009;30:143-5.

14. Haponik EF, Meyers DA, Munster AM, Smith PL, Britt EJ, Wise RA, et al. Acute upper airway injury in burn patients. Serial changes of flow-volume curves and nasopharyngoscopy. Am Rev Respir Dis 1987;135:360-6.

15. Fitzpatrick J, Cioffi Jr. WG. Diagnosis and treatment of inhalation injury. In: Herndon D, editor. Total burn care. London: Saunders; 1996. p. 184-92.

16. Stauffer JL, Olson DE, Petty TL. Complications and consequences of endotracheal intubation and tracheotomy. A prospective study of 150 critically ill adult patients. Am J Med 1981;70:65-76.

17. Smailes ST. Noninvasive Positive Pressure Ventilation in burns. Burns 2002;28:795-801.

18. Peck MD, Koppelman T. Low-tidal-volume ventilation as a strategy to reduce ventilator-associated injury in ALI and ARDS. J Burn Care Res 2009;30:172-5.

19. Cancio LC, Chávez S, Alvarado-Ortega M, Barillo DJ, Walker SC, McManus AT, et al. Predicting increased fluid requirements during the resuscitation of thermally injured patients. J Trauma 2004;56:404-14.

20. Soejima K, Schmalstieg FC, Sakurai H, Traber LD, Traber DL. Pathophysiological analysis of combined burn and smoke inhalation injuries in sheep. Am J Physiol Lung Cell Mol Physiol 2001;280:L1233-41.

21. Enkhbaatar P, Herndon DN, Traber DL. Use of nebulized heparin in the treatment of smoke inhalation injury. J Burn Care Res 2009;30:159-62.

22. Brown M, Desai M, Traber LD, Herndon DN, Traber DL. Dimethylsulfoxide with heparin in the treatment of smoke inhalation injury. J Burn Care Rehabil 1988;9:22-5.

23. Desai MH, Mlcak R, Richardson J, Nichols R, Herndon DN. Reduction in mortality in pediatric patients with inhalation injury with aerosolized heparin/ $\mathrm{N}$-acetylcystine [correction of acetylcystine] therapy. J Burn Care Rehabil 1998;19:2102.

24. Nguyen TT, Cox CS, Traber DL, Gasser H, Redl H, Schlag $\mathrm{G}$, et al. Free radical activity and loss of plasma antioxidants, vitamin E, and sulfhydryl groups in patients with burns: the 1993 Moyer Award. J Burn Care Rehabil 1993;14:602-9.

25. Kahn SA, Beers RJ, Lentz CW. Resuscitation after severe burn injury using high-dose ascorbic acid: a retrospective review. J Burn Care Res 2011;32:110-7. 